\title{
Approval of Credit Lines for Legal Entities at Banco Do Brasil: An Application of the Multicritery Method of Decision Support
}

Bruno Oliveira Pinto Cardoso ( $\sim$ bruno.mkt@gmail.com )

SENAI CIMATEC Technology College: Faculdade de Tecnologia SENAI CIMATEC https://orcid.org/0000-0002-4501-0275

Hugo Saba Pereira Cardoso

UNEB: Universidade do Estado da Bahia

José Vicente Cardoso Santos

UNEB: Universidade do Estado da Bahia

Renelson Ribeiro Sampaio

SENAI CIMATEC Technology College: Faculdade de Tecnologia SENAI CIMATEC

Research article

Keywords: Credit lines, Multicriteria methodology, Banco do Brasil.

Posted Date: March 30th, 2021

DOI: https://doi.org/10.21203/rs.3.rs-296136/v1

License: (9) This work is licensed under a Creative Commons Attribution 4.0 International License.

Read Full License 


\title{
APPROVAL OF CREDIT LINES FOR LEGAL ENTITIES AT BANCO DO BRASIL: AN APPLICATION OF THE MULTICRITERY METHOD OF DECISION SUPPORT
}

\author{
Bruno Oliveira Pinto Cardoso ${ }^{a}$, Hugo Saba Pereira Cardoso ${ }^{b}$, José Vicente Cardoso \\ Santos $^{c}$, Renelson Ribeiro Sampaio ${ }^{d}$
}

\footnotetext{
a, Banco do Brasil, Brasil, Senai/Cimatec, E-mail: bruno.mkt@gmail.com, End.: Rua Desembargador Manoel Pereira, 130. Apto 103. Costa Azul. CEP. 41.760-150.

b, Universidade Estadual da Bahia (UNEB), Brasil, E-mail: hugosaba@gmail.com.

', Universidade Estadual da Bahia (UNEB) e Centro Universitário SENAI-CIMATEC, Brasil, E-mail: prof.vicentecardoso@gmail.com

`, Centro Universitário SENAI-CIMATEC, Brasil, E-mail: renelson.sampaio@fieb.org.br
}

\begin{abstract}
The problem of the decision-making process in the granting of bank credit lines at Banco do Brasil is considered and a proposal for the application of the multicriteria method for its decision is listed. With this, the general objective of the research is the description of algorithm and multicriteria mapping in the offer and selection of credit lines for legal entities at Banco do Brasil. To consolidate these objectives, a methodology based on a literature review of bibliographic references is adopted, in the search for information in the bank's own portfolios in a universe suitable for clients in the modality of legal entity in the universe of Banco do Brasil. The singular production of the research is a proposal for a strategy for selecting credit lines as well as offering recommendations for dealing with the topic and the like.
\end{abstract}

Keywords: Credit lines. Multicriteria methodology. Banco do Brasil.

\section{APROVAÇÃO DE LINHAS DE CRÉDITO PARA PESSOA JURÍDICA NO BANCO DO BRASIL: UMA APLICAÇÃO DO MÉTODO MULTICRITÉRIO DE APOIO Á DECISÃO}

Resumo: Considera-se a problemática do processo decisório na concessão de linhas de crédito bancário no Banco do Brasil e elenca-se uma proposta de aplicação do método multicritério para a decisão do mesmo. Com isto o objetivo geral da pesquisa é a descrição de algoritmo e mapeamento multicritério na oferta e na seleção de linhas de crédito para pessoa jurídica no Banco do Brasil. Para consolidar estes objetivos adota-se uma metodologia lastreada em revisão de literatura das referências bibliográficas, nas pesquisas de informações nas carteiras do próprio banco em universo próprio para clientes na modalidade de pessoa jurídica no universo do Banco do Brasil. A produção singular da pesquisa é uma proposta de estratégia de seleção das linhas de crédito bem como a oferta de recomendações ao trato do tema e afins.

Palavras-chave: Linhas de crédito. Metodologia multicritério. Banco do Brasil. 


\section{INTRODUCTION}

The Brazilian banking system has a strong identification with Banco do Brasil, as it was created to encourage credits and support the movement of an imperial Brazil, but in a frank commercial expansion and at present this scenario is no different because it is constituted in the form of mixed capital company and which has a direct participation of the Union itself in around $68.7 \%$ of the shares in addition to operating in more than eighteen thousand service stations that are currently distributed throughout Brazil and abroad between branches and various service stations with presence in more than twenty countries with more than one hundred thousand employees ${ }^{1,2}$.

The offer of credit lines is common and in the specific case of Banco do Brasil there is a diversified offer of credit lines that need to be adjusted to the criteria established by the bank so that the choice process is more appropriate and compatible with the demands of the bank. client (individual) is now defined by the Bank, although it is not yet automated and therefore deserves to be considered by management with possible mistakes ${ }^{3}$.

With this scenario in mind, the general objective of this research is the description of algorithm and multicriteria mapping in the offer and selection of credit lines for legal entities at Banco do Brasil and to consolidate this objective, a methodology that uses a review of literature, of historical and documentary nature 4 with a study of the multicriteria methodology of decision support as well as a case study with action research at "Banco do Brasil", thus substantiating a hybrid research focusing on a case study with real data with no exposure of data from the bank or those listed companies, however, the data provided are real and compatible with the current business scenario in Brazil4,5,6, it also deserves to consider that the descriptors are constructed through fundamental points of view, so that, the consideration of two-way correspondence for each credit line with a set of fundamental and specific points of view for each of the lines creating im a cardinal scale for each line and thus the deployment of alternative methods and thus following the philosophy and fundamental principles of the MCDA (Multicriteria Decision Support Methodology) $)^{7,8,9}$.

Formally, the multicriteria methods of decision support can be defined as an activity, or set of activities, in which the facilitator, in a scientific way, aims at obtaining elements that answer questions raised by decision makers in a decisionmaking process, so that these elements help in the process of understanding your decision ${ }^{10,11,12,13}$.

There are three types of actors, to mention: decision makers, representatives and the facilitator, and so-called decision makers are those to whom decision-making power has been formally or morally delegated; the representative, who is that actor assigned by the decision maker to represent him in the decision support process; and, finally, there is what is called Facilitator and who is also an actor in the decisionmaking process, since he will never be neutral in the decision support process and, therefore, influences him $^{14,15}$.

It deserves to be considered that the fundamental points of view (PVF's) represent the facilitator's expertise and that they are reflected in the decision process perceived as being of important construction of what will be at the end, that is, a model for evaluating actions ${ }^{16}$ where these properties demand a set of concepts of intelligibility, consensuality, operability and isolability where the characteristics of 
PVF's allow it to be reflected in its own way and with the perception of the facilitator in order to reflect its expertise and also with its improvement ${ }^{12,17,18}$.

\section{RESULTS AND DISCUSSION}

The main characteristics that are necessary for each credit line can be classified into classes or categories and the use of them allows to build or map this information based on the questions that are asked interactively between customers so that operators, in general managers, can search for the line or lines that fit the customer's profile, as listed in Table 1, below:

Table 1 Lines of Credit and their respective purposes

\begin{tabular}{|l|l|}
\hline \multicolumn{1}{|c|}{ Credit Line } & \multicolumn{1}{c|}{ Purpose } \\
\hline Quick Turn of Credit to & Reinforcement of Working Capital \\
\hline $\begin{array}{l}\text { Anticipation } \\
\text { Tenants (ACL) }\end{array}$ & Anticipation of the net value of sales made with cards. \\
\hline BNDES Card & Finances machines, equipment, production goods. \\
\hline Guaranteed account & Reinforcement of Working Capital \\
\hline Checks Discount & Anticipation of the net sales value. \\
\hline Business Finame & For the purchase, production or sale of machinery. \\
\hline Finame Empresarial PSI & $\begin{array}{l}\text { Finance the acquisition and production of machines via } \\
\text { BNDES. }\end{array}$ \\
\hline Finame Modermaq & Finance the purchase of machinery and equipment \\
\hline Giro Flex Company & $\begin{array}{l}\text { Reinforcement of Working Capital and acquisition of goods } \\
\text { and services. }\end{array}$ \\
\hline $\begin{array}{l}\text { Giro Empresa Flex - Structured } \\
\text { Releases }\end{array}$ & $\begin{array}{l}\text { Capital strengthening and financing for the acquisition of } \\
\text { goods and services, export credit. }\end{array}$ \\
\hline Giro Mix PASEP & Reinforcement of working capital \\
\hline Cash Receivables & Reinforcement of working capital \\
\hline Proger Turismo Investment & $\begin{array}{l}\text { Financial support for working capital associated with projects } \\
\text { in the tourism sector. }\end{array}$ \\
\hline Proger Urbano Empresarial & $\begin{array}{l}\text { Financial support for investments with working capital for } \\
\text { micro and small companies. }\end{array}$ \\
\hline
\end{tabular}

The proposal to algorithmize the use of this information allows us, with the use of the multicriteria method, where each possible class of credit lines is described with its possible and respective conditions for their adherence as shown in the following mathematical relationship, which, using the TODIM method (Multicriteria Interactive Decision Making) $)^{6,8,11}$, where the analyzed variables reflect the problem under analysis with their weights and respective normalized values, ie:

$$
\text { Punctuation }=\left[\begin{array}{ll}
(F+P A+R C+R O+L C V+L R+C C)^{\{0,1\}}+ \\
\frac{(L L+G)^{\{1,2,3,4,5\}}}{5}
\end{array}\right] * 10 / 9 \quad \text { Eq. } 1
$$

where the variables and notation can be understood as being: " $F "$ the purpose, "PA" the target audience, "RC" the client risk, "RO" the operation risk, "LCV" the current credit limit, "LR" the release of funds, and the "CC" the Cielo affiliation, collection or custody, and the "LL" the line limits, and " $G$ " the guarantees. It is also worth considering that the values thus total a maximum score that can 
always be renormalized when new items are effectively learned and implemented, however, in this adopted version we have to:

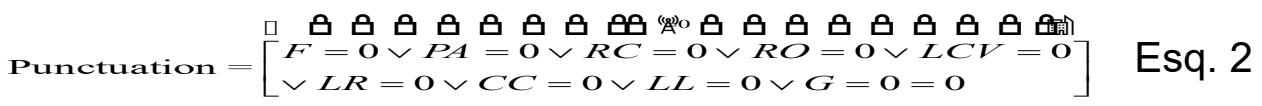

This expression then proceeds to determine a weighted average by class and by categories of questioning so that the entire score can be configured and with this maximize the results so that their classification can occur in order of the power of their results, where, the largest will always be the most scored, thus having a scale of priority and optimization of supply for the respective credits under analysis.

\section{CONCLUSION}

The modeling proposal presented is configured in a matrix formation of opportunities associated with the supply matrix of credit lines in banks in addition to the description of the various lines used. It is also worth considering that an algorithmic modeling of how to weigh and normalize the presented credit system was also presented and it is still possible to generate a punctuated numerical scale.

The research objectives were also consolidated with the implementation of credit line modeling and the description of normative instructions associated with a normalizable numerical scale, in addition to the fact that these processes can be implemented in simple software (spreadsheets and even high-level languages). level etc.), in addition, the Manager himself can use this and have an effective tool available for the management decision-making process.

This presents yet another credit assessment instrument with the advantage of being quick to apply and transparent to the investor, the Manager and employees and also the client, and, finally, it is also recommended that similar procedures and spreadsheets be created for other areas while it is recommended, for future work, a deeper use of these credit rules, in their various legal and normative bases, in the analysis of trends and megatrends and in the literature review in the area.

\section{List of Abbreviations}

ACL - Advance of Credit to Tenants.

MCDA - Multicriteria Decision Support Methodology.

PVFs - Fundamental points of view.

TODIM - Multicriteria Interactive Decision Making.

\section{Availability of data and materials}

The transparent texts in this document are available in machine-readable format on the Banco do Brasil website (https://www.bb.com.br) and can be used free of charge.

\section{REFERENCES}

${ }^{1}$ BRESSER-PEREIRA, Luiz Carlos. (1988). A reforma do estado dos anos 90: lógica e mecanismos de controle. Lua Nova: Revista de Cultura e Política, São 
Paulo, n. 45, p.49-95. Disponível em:

<http://www.clad.org.ve/fulltex/0030101.html>. Acesso em: 28 ago. 2016.

2 BANCO CENTRAL DO BRASIL. (2020). Disponível no site https://www.bcb.gov.br/pre/ composicao/bm.asp.

${ }^{3}$ BRANDÃO, M. A. L. (2010). Estudo de alguns métodos determinísticos de otimização irrestrita. Uberlândia. 87p.

${ }^{4}$ CERVO, A. L. \& BERVIAN, P. A. (2011). Metodologia Científica. $6^{a}$ ed. São Paulo, Makron Books.

${ }^{5}$ RUIZ, João Álvaro. (2015). Metodologia científica: guia para eficiência nos estudos. 9a. ed. São Paulo: Atlas.

${ }^{6}$ ENSSLIN, L; NETO, G. M.; NORONHA, S. M. (2001). Apoio à Decisão Metodologia para Estruturação de Problemas e Avaliação Multicritério de Alternativas. Florianópolis: Insular.

${ }^{7}$ CORREAA, C. E. (1996). Construção de um Modelo Multicritério de Apoio ao Processo Decisório. Florianópolis - Brasil. Dissertação de Mestrado. Depto. De Engenharia de Produção, Universidade de Santa Catarina.

${ }^{8}$ ANDRADE, E. L. (2009). Introdução à pesquisa operacional: métodos e modelos para análise de decisões. Rio de Janeiro: LTC.

${ }^{9}$ ALVES, Sérgio D. S.; SOARES, Marden Marques. (2004). Democratização do crédito no Brasil: atuação do Banco Central. Banco Central do Brasil. Disponível em: <http://www.bcb.gov.br>. Acesso em: 12 jul. 2020.

${ }^{10}$ KEENEY, R. L.; RAIFFA, H. (1976). Decision with Multiple Objectives: Preferences and Value Trade-offs. John Wiley \& Sons.

${ }^{11}$ RAGSDALE, C.T. (2009). Modelagem e análise de decisão. São Paulo: Cengage Learning.

${ }^{12}$ BANA E COSTA, C. A. (1986). Apoio à Tomada de Decisão segundo Critérios Múltiplos. IST/CESUR. Lisboa.

${ }^{13}$ ROY, B. (1993). Decision science or decision-aid science. European Journal of Operational Research 66. p. 184-203.

${ }^{14}$ SCHWARZ, R. M. (1994). The Skilled Facilitator. San Francisco: Jossey-Bass.

${ }^{15}$ COSTA NETO, Yttrio Corrêa. (2004). Bancos oficiais do Brasil: origem e aspectos do seu desenvolvimento. Brasília: Banco Central do Brasil. 82 p. 
${ }^{16}$ GOMES, L. F. A M.; LIMA, C. F. S. (2012). Tomada de Decisão Gerencial:

Enfoque Multicritério. $3^{a}$. ed. rev. atual. e ampl. São Paulo: Atlas.

${ }^{17}$ GOMES, L. F. A. M. (2004). Teoria da Decisão. São Paulo: Thomson Learning.

${ }^{18}$ ROY, B. VANDERPOOTEN, D. (1996). The European School of MCDA:

Emergence, basic features and current works. Journal of Multicriteria Decision Analysis, v. 5, pp. 22-38.

\section{Acknowledgments}

We thank SENAI CIMATEC, Banco do Brasil, UNEB (Universidade do Estado da Bahia), CNPq.

\section{Financing}

SENAI CIMATEC, Banco do Brasil, UNEB (Universidade do Estado da Bahia), CNPq and FAPESB.

\section{Author Information}

Bruno Oliveira Pinto Cardoso - Employee / Manager of Banco do Brasil, Brazil, Senai / Cimatec, E-mail: bruno.mkt@gmail.com, End .: Rua Desembargador Manoel Pereira, 130. Apt 103. Costa Azul. ZIP CODE. 41,760-150.

Hugo Saba Pereira Cardoso is Professor at the State University of Bahia (UNEB) Brazil, E-mail: hugosaba@gmail.com.

José Vicente Cardoso Santos is a Professor at the State University of Bahia (UNEB) and Centro Universitário SENAI-CIMATEC, Brazil, E-mail: prof.vicentecardoso@gmail.com.

Renelson Ribeiro Sampaio is a Professor at the Centro Universitário SENAICIMATEC, Brazil, E-mail: renelson.sampaio@fieb.org.br.

\section{Statements}


Ethical Approval and Consent to Participate

The authors ratify the ethical aspects in the production of the work at the time they agree with their participation in editing the work.

\section{Consent for publication}

The authors agree and authorize the publication of the work.

\section{Supporting data availability}

The authors become available to complement data in support of the published and on the results of the research.

\section{Competitive interests}

Not applicable. 